\title{
FLASH PROFILE AS A RAPID DESCRIPTIVE ANALYSIS IN SENSORY CHARACTERIZATION OF TRADITIONAL DRY FERMENTED SAUSAGES
}

\author{
Dubravka J. Škrobot* ${ }^{*}$, Jelena M. Tomić ${ }^{1}$, Tamara R. Dapčević Hadnađev ${ }^{1}$, Aleksandra R. Novaković ${ }^{1}$, \\ Miroslav S. Hadnađev ${ }^{1}$, Jovana D. Delić ${ }^{1}$, Muamer J. Mandra ${ }^{2}$ \\ ${ }^{1}$ University of Novi Sad, Institute of Food Technology, 21000 Novi Sad, \\ Bulevar cara Lazara 1, Serbia \\ ${ }^{2}$ Perutnina Ptuj BH d.o.o., 71370 Breza, Potkrajska bb, Bosnia and Herzegovina
}

\author{
*Corresponding author: \\ Phone: +381214853780 \\ Fax: +38121450725 \\ E-mail address: dubravka.skrobot@fins.uns.ac.rs
}

\begin{abstract}
Traditionally, sensory analysis techniques are separated on those performed with trained sensory panellists (analytical procedures) and those with consumers (hedonic tests). Nowadays, dividing line between these two approaches tends to blur. Following industrial needs for faster and more cost-effective methods of descriptive sensory profiling, several methods have been developed as alternatives to classical descriptive analysis. This study aimed to evaluate the samples, three of commercial and three of traditionally produced dry fermented sausages using the Flash Profile (FP) as a rapid descriptive analysis method, in which a panel of 10 sensory experts chose and used his/her own words to evaluate the sausage samples while comparing several attributes. Total of 24 sensory attributes were chosen by the panel, and each assessor used from 9 to 16 sensory descriptors. The obtained results for the samples ranks were collected within matrices, and were analysed by using a multivariate statistical technique General Procrustes Analysis (GPA). The first two dimensions explained about $76.49 \%$ of data variability (Dimension 1: $57.23 \%$ and Dimension 2: $19.26 \%$ ). A good discrimination between traditional $(B, C$ and $D)$ and commercial ( $A, E$ and $F$ ) dry fermented sausages was observed. The obtained results of Flash profile proved to be a quick substitute method and also a good help as an initial comprehension of the most important attributes of a product's set.
\end{abstract}

Key words: flash sensory profile, rapid descriptive sensory analysis, dry fermented sausages, Generalized Procrustes Analysis

\section{INTRODUCTION}

Descriptive sensory profiling has been extensively used by food and beverage industries for different purposes. Defining and quantifying sensory characteristics has been used in product quality control, for giving directions for new product development and improvement, to check the effect of ingredients or processes, to determine product shelf life, to establish correlation with instrumental and analytical measurements, as a tool for understanding consumer preferences (Lawless and
Heymann, 2010; Moussaoui and Varela, 2010; Stone and Sidel, 2004). There are several different classical methods of descriptive sensory analysis (Figure 1) which reflect various sensory philosophies and approaches. However, all these approaches had one thing in common; they have to be used with highly trained panels in terms of sensory recognition, characterization, evaluation and scaling of the selected attributes for the particular sample set. 
Although classical descriptive analysis provides detailed, specific and precise description of products' sensory properties with reliable and reproducible results, establishing and maintaining a well-trained calibrated sensory panel can be relatively long and usually expensive. However, the formation of sensory panel from the beginning is not justified and possible if you have short projects with limited budget or industry requires quick responses to market (Varela and Ares, 2012). Bearing all these in mind, it was evident that sensory scientists had to provide faster and more adjustable new sensory methodologies that would overcome some of constrains of time and resources of classical descriptive analysis while maintaining the reliability of the obtained results (Delarue, 2014; Delarue and Sieffermann, 2004; Varela and Ares, 2012).

Several new methodologies of sensory profiling have been developed as alternatives to classical sensory descriptive analysis in the last years (Figure 1). These methods can provide quick results regarding the relative sensory positioning of a set of food products and since they do not require training phase, they can be used with semi-trained or naïve assessors. In general, novel techniques are based on different approaches - methods that evaluate individual products' attributes (verbal based methods); methods that evaluate overall differences (similarity-based methods); methods based on comparison with reference product (reference-based methods) (Valentin et al., 2012).

There are several review papers that are dealing with the implementation, advantages and disadvantages of the novel sensory profiling techniques application (Andrade de Aguiar et al., 2019; Varela and Ares, 2012; Valentin et al., 2012). According to Valentin et al. (2012), verbal based methods are more discriminant, more detailed and provide descriptions that are easy to understand, in contrast to the similarity-based methods that are suitable for understanding overall information about products' sensory properties. Delholm et al. (2012) showed the advantage of flash profiling (FP) in comparison to Napping and ultra-flash profiling, as well. Comparing verbal-based methods, FP is more time consuming than CheckAll-That-Apply method (CATA) and may lead to more saturation problems, however its- advantage is that it provides ordinal data rather than just frequencies.

The Flash Profile is a method that gives a high degree of freedom to the assessors in choosing and using their own sensory language and promotes an individual approach in selection of product attributes that would be used for ranking of samples on these attributes (Bredie et al., 2018). The FP method is a variant of free choice profiling (FCP), which combines FCP in attribute selection and a simultaneous comparison of the all products set through the ranking (Dairou and Sieffermann, 2002). It relies on the fact that it is easier to compare products with each other than to evaluate them on an absolute scale (Valentin et al., 2012).

Flash profile has been applied to describe many different foods including fruit products and beverages (Blancher at al., 2007; Dairou and Sieffermann, 2002; Delarue and Sieffermann, 2004; Jaros et al., 2009; Tarea et al., 2007; Veinand et al., 2011), chewing gum (Delarue and Loecher, 2004), bread (Lasoued et al., 2007), fish nuggets (Albert et al. 2011). According to authors' knowledge, there is a limiting number of articles referencing to sensory analysis of traditional products such as dry fermented sausages, by using Flash Profiling method (Rason et al., 2006). Bearing in mind that dry sausages are part of the traditional products across Europe and the Western Balkans that receive real success with consumers nowadays, with this paper the authors aimed, through reviewing theory, implementation, advantages and disadvantages of the Flash profile technique, to evaluate appropriateness of this method to be used as a tool for differentiation between commercially available dry fermented sausages with those that are produced more traditionally. The relevance of this research is justified by the fact that consumers are able to differentiate traditional products from industrial by the sensory diversity of traditional products (Rason et al., 2006). 


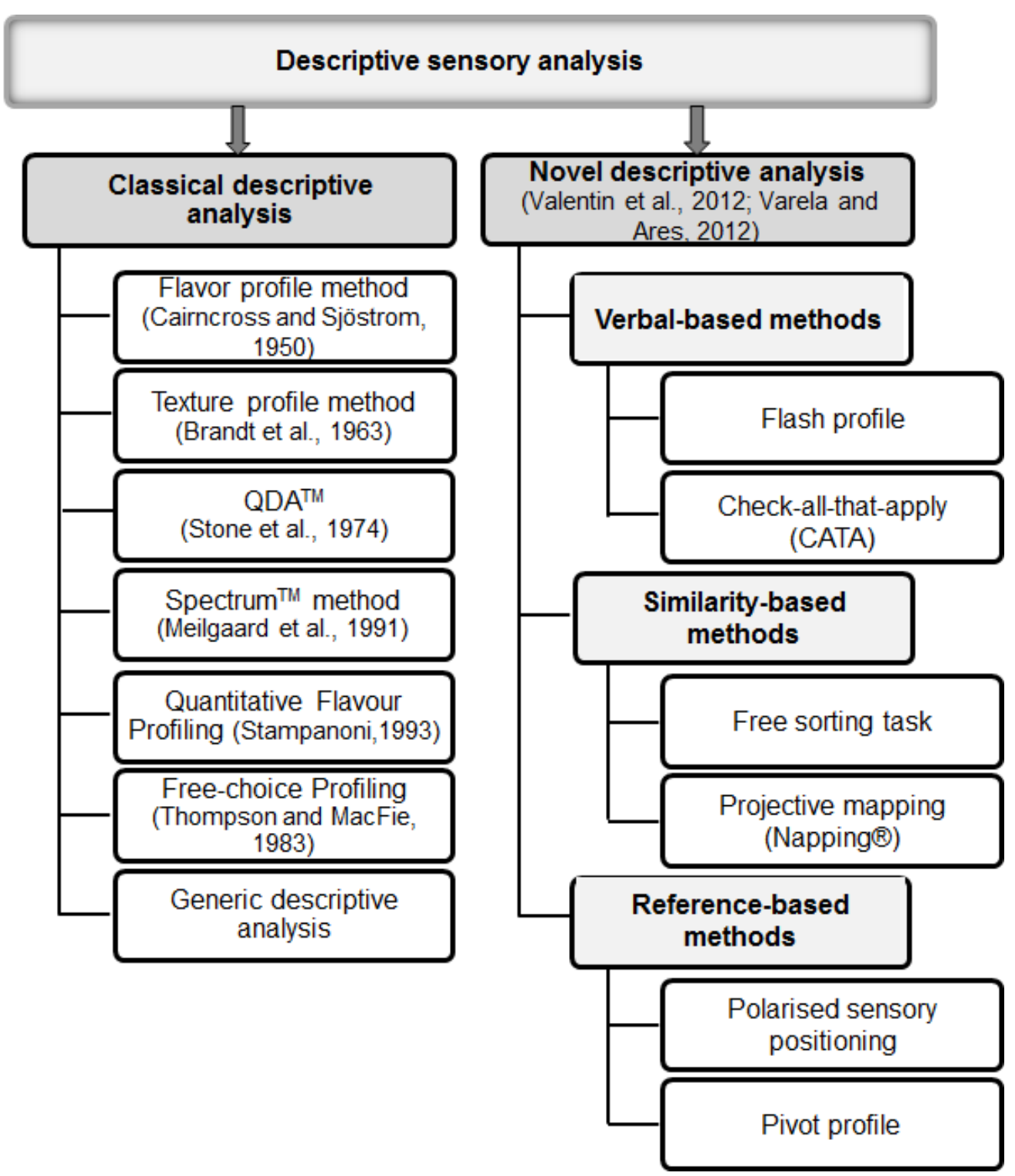

Figure 1. Schematic presentation of the descriptive sensory analysis classification

\section{MATERIALS AND METHODS}

\section{Samples}

In the present study, a product is considered traditional if it is manufactured by a smallholder who applies a traditional process, uses raw material from his farm, avoids the use of additives and commercializes the products by himself or under his responsibility. Six samples (Figure 1), three of commercial and three of traditionally produced dry fermented sausages were analysed. Samples of traditionally produced dry fermented sausages were procured directly from the producers whereas commercial samples were purchased from the local market. Selection of the samples was based on the brand popularity and the fact that the samples are more consumed in the region. Table 1 presents the composition of the samples. The samples were coded with capital letters, from $A$ to $F(A, E$ and $F$ were used for commercially available samples and $\mathrm{B}, \mathrm{C}$ and $D$ for traditionally produced sausages) instead of three-digit numbers in order to prevent mistakes and omissions when reporting the ranks on the score sheet (Delarue, 2014) (Figure 2).

\section{Flash profile of the dry fermented sausages}

A panel of 10 sensory experts (7 women and 3 men, aged from 34 to 45 years) was 
recruited for performing Flash Profile analysis. All assessors were recruited from the Institute of Food Technology, Novi Sad, and assessors did not need to participate in the tasting sessions at the same time. Assessors had experience in classical sensory profile analysis while two of them possess specific experience in dry sausages production, as well. The procedure of Flash Profile consisted of two sessions, both with different tasks, and with an intersession between them. In the first session, the whole set of samples was presented simultaneously to assessors who were asked to create his/her own set of attributes that best describe differences between the samples. The assessors were instructed to generate as many descriptive attributes as they want, but to avoid hedonic terms. Furthermore, they were advised to arrange terms according to sense modality (appearance, odour, taste, flavour, texture, mouthfeel, sound) and to re-taste sample as often as they want and can take as much time as they need. The process of attributes generation lasted around 40-60 $\min$.

Inter-session was oriented in providing a pooled list of generated attributes to the assessors. The idea of this integrated list of attributes is to enable assessors to update their own list if they want. The assessors are allowed to add new terms or to replace their own terms with those more appropriate.

During the second, final session, the assessors ranked samples in order of the perceived level of intensity, from "low" to "high", on each of the attributes from their list. Furthermore, it was allowed for the samples with the same perceived intensity to share the same rank number (ties).

\section{Data collection and analysis}

Before data analysis, it was necessary to correctly read ranking positions of the samples and put them in the data matrices. In Figure 3 is example of Flash Profile sheet and explanation how ranking data has to be evaluated. The sample with the lowest intensity was given a rank 1 and then with increasing of the sensory intensity, the rank positions were increasing accordingly. For samples which share rank positions (tied samples), a mean rank value was given. To verify whether the entered ranks are correct, it was necessary to check the sum of ranks, which has to be the same for all attributes and all assessors. With collected data for each assessor the matrices with products in rows and attributes in columns were built.
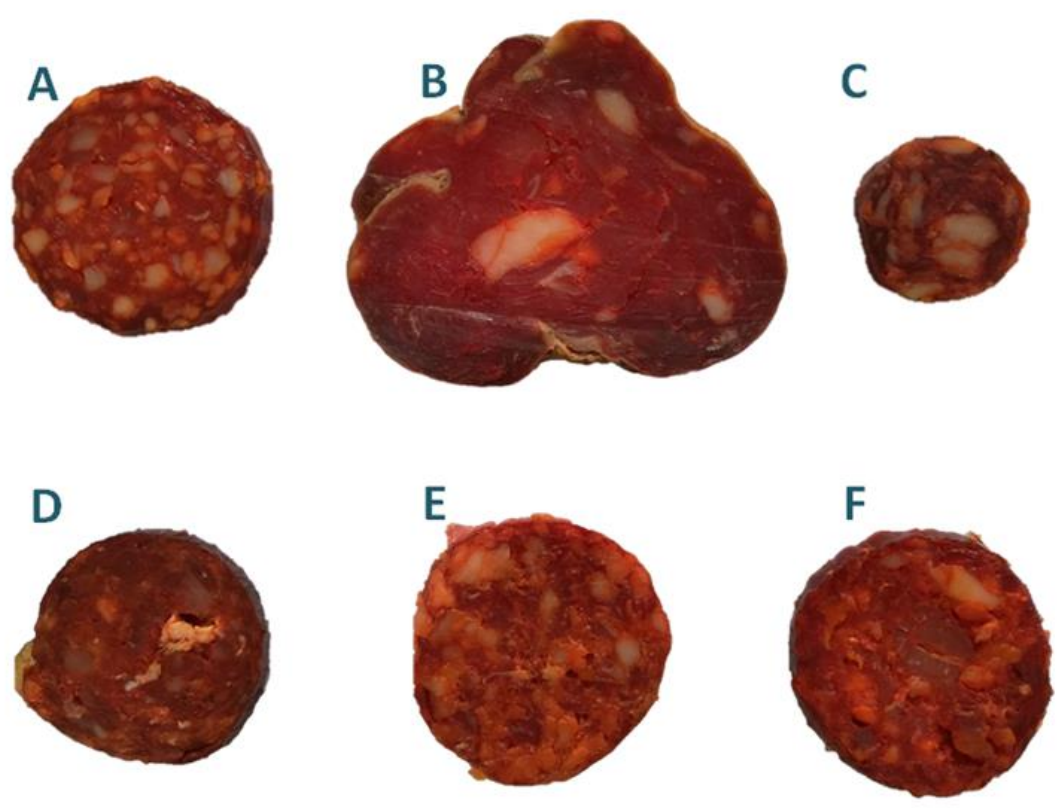

Figure 2. Cross section of dry fermented sausages 
Table 1.

List of ingredients and processing conditions for analysed dry fermented sausage samples

\begin{tabular}{|c|c|}
\hline Samples & Ingredients and processing conditions \\
\hline A & $\begin{array}{l}\text { Pork meat (I category), backfat, } \mathrm{NaCl} \text {, spices, acidity regulator glucono delta- } \\
\text { lactone (E575), sugars, antioxidant ascorbic acid (E300), preservative sodium } \\
\text { nitrite (E250) and sodium nitrate (E251) } \\
\text { artificial casing } \\
\text { smoking and fermentation - ca } 4 \text { days } \\
\text { drying and ripening - ca } 5 \text { weeks }\end{array}$ \\
\hline $\mathrm{B}$ & $\begin{array}{l}\text { Pork meat (I category), backfat, } \mathrm{NaCl} \text { and red paprika powder (sweet and hot) } \\
\text { natural casing (pig appendix) } \\
\text { smoking and fermentation - ca 10- } 15 \text { days } \\
\text { drying and ripening - ca 5- } 6 \text { months }\end{array}$ \\
\hline C & $\begin{array}{l}\text { Pork meat (II and III category), } \mathrm{NaCl} \text {, red paprika powder (sweet and hot), } \\
\text { garlic and ground peper } \\
\text { natural casing (pig small intestine) } \\
\text { smoking and fermentation - ca } 6-7 \text { days } \\
\text { drying and ripening - } 2 \text { weeks minimum }\end{array}$ \\
\hline $\mathrm{D}$ & $\begin{array}{l}\text { Pork meat (I and II category), backfat, } \mathrm{NaCl} \text {, red paprika powder (sweet and } \\
\text { hot), raw garlic paste, caraway and sugar } \\
\text { natural casing (pig rectum) } \\
\text { smoking and fermentation - ca } 10 \text { - } 15 \text { days } \\
\text { drying and ripening - ca } 3-4 \text { months }\end{array}$ \\
\hline$E$ & $\begin{array}{l}\text { Pork meat I category, back fat, } \mathrm{NaCl} \text {, spices and spices extracts, dextrose, } \\
\text { sugar, acidity regulator gluconodelta-lactone (E575), preservative sodium } \\
\text { nitrite (E250), antioxidant ascorbic acid (E300) } \\
\text { artificial casing } \\
\text { smoking and fermentation - ca } 4 \text { days } \\
\text { drying and ripening - ca } 5 \text { weeks }\end{array}$ \\
\hline $\mathrm{F}$ & $\begin{array}{l}\text { Pork meat I category, back fat, } \mathrm{NaCl} \text {, spices, sugars, antioxidant ascorbic acid } \\
\text { (E300), preservative sodium nitrite (E250) and starter culture } \\
\text { artificial casing } \\
\text { smoking and fermentation - ca } 4 \text { days } \\
\text { drying and ripening - ca } 5 \text { weeks }\end{array}$ \\
\hline
\end{tabular}

\begin{tabular}{|c|c|c|c|c|c|c|c|c|}
\hline \multirow[b]{2}{*}{ Attribute 1} & & & \multirow{3}{*}{$\begin{array}{l}\text { C } \\
\text { D }\end{array}$} & \multirow{3}{*}{$\begin{array}{l}E \\
F\end{array}$} & & \multicolumn{3}{|c|}{ Assessor 1} \\
\hline & & & & & \multirow[b]{2}{*}{ High } & Sample & Attribute 1 & Attribute 2 \\
\hline \multirow[t]{3}{*}{ Low } & A & B & & & & A & 1 & 2 \\
\hline & & & & & & B & 2 & 2 \\
\hline & & & & & & c & 3.5 & 2 \\
\hline \multirow{4}{*}{$\begin{array}{c}\text { Attribute } 2 \\
\text { Low }\end{array}$} & & & & & & D & 3.5 & 4 \\
\hline & & & D & $\mathbf{E}$ & High & E & 5.5 & 5 \\
\hline & & & & & & $\mathrm{F}$ & 5.5 & 6 \\
\hline & & & & & & $\begin{array}{l}\text { Ranks } \\
\text { sum }\end{array}$ & 21 & 21 \\
\hline
\end{tabular}

Figure 3. An example of Flash Profile ranking sheet (left) and data table with ranks corresponding to the ranking sheet

The FP results for samples ranks were collected within matrices, and were analysed by using multivariate statistical tech- nique General Procrustes Analysis (GPA). This technique was performed to minimize individual differences and to obtain a con- 
sensus between assessors" sensory maps. It also allows comparing the proximity between the terms that are used by different experts to describe products. GPA provided a product and an attribute biplot map that was used for both, to check panel consensus and to discriminate among samples based on the observed sensory attributes.

The statistical analysis was performed by using XLSTAT software (version 2019.3.2, Addinsoft).

\section{RESULTS AND DISCUSSION}

General Procrustes Analysis (GPA) through several tables and corresponding charts (residuals by object and residuals by configuration) provides information on reached consensus within panel in terms of evaluated samples and scale usage. Analysing these results (data not shown), it was evident that consensus was obtained between assessors, since residuals were low and similar across objects and assessors.

Within Flash profile method, total of 24 sensory attributes were chosen by the panel, and each assessor used from 9 to 16 sensory descriptors (Table 2).

All assessors recognised red colour intensity, saltiness and acidic taste among samples. The other attributes with the highest frequency of occurrence were cross section regularity, smoked odour, odour on lactic acid, spicy and smoked flavour. The GPA consensus biplot map

Table 2.

Sensory attributes used for the evaluation of the dry fermented sausages by using Flash profile method

\begin{tabular}{llll}
\hline Attributes & \multicolumn{1}{c}{ Flash profile descriptors } & $\begin{array}{c}\text { Frequency of } \\
\text { occurrences }\end{array}$ & Abbreviation \\
\hline Appearance & Red colour intensity & 10 & $\mathrm{Rci}$ \\
& Colour intensity on edges & 2 & $\mathrm{Eci}$ \\
& Edge thickness & 3 & $\mathrm{ET}$ \\
& Cross section regularity & 8 & $\mathrm{CSr}$ \\
& Cross section particle size & 2 & $\mathrm{CSps}$ \\
& Cross section particles regularity & 3 & $\mathrm{CSpr}$ \\
& Regularity of meat and fat particles size & 2 & $\mathrm{MFpr}$ \\
& Fat particles regularity & 1 & $\mathrm{FPr}$ \\
& Fat phase content & 1 & $\mathrm{Fpc}$ \\
& Fat phase visibility & 2 & $\mathrm{Fpv}$ \\
& Presence of connective tissue & 3 & $\mathrm{CTp}$ \\
\hline Odour & Smoked odour & 8 & SmO \\
& Odour on lactic acid & 8 & AcO \\
& Odour of spices & 4 & SpO \\
\hline Flavour & Saltiness & 10 & saltiness \\
& Acidic taste & 10 & acidic taste \\
& Smoked flavour & 8 & smoked flavour \\
& Flavour of ripe meat & 2 & RMf \\
& Flavour of meat & 1 & Mf \\
& Spicy & 8 & spicy \\
\hline Texture & Hardness & 6 & hardness \\
& Chewiness & 6 & Chew \\
& Cohesiveness & 1 & Coh \\
& Easiness to separate outer wrapper & 5 & OW \\
\hline
\end{tabular}




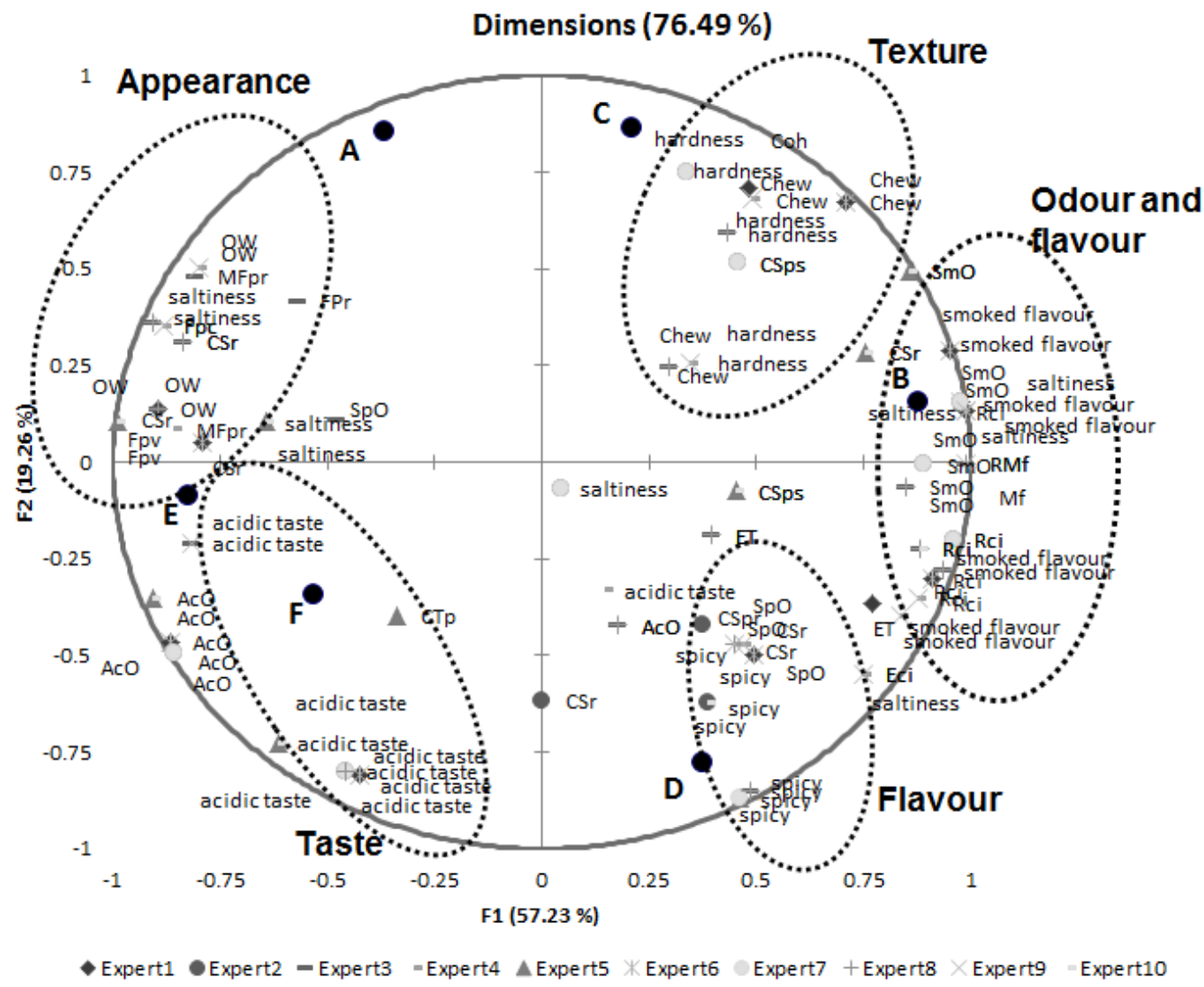

Figure 4. Biplot map of General Procrustes Analysis performed on Flash Profile data

is presented in Figure 4. The first two dimensions explained about $76.49 \%$ of data variability (Dimension 1: $57.23 \%$ and Dimension 2: 19.26\%). Generally, good discrimination between traditional $(B, C$ and $D$ ) and commercial (A, E and F) dry fermented sausages was observed. Samples differentiation on Dimension 1 was mainly based on appearance and odour and flavour characteristics. On the other hand, Dimension 2 separated samples based on different taste and textural properties.

On the correlation circle, dry fermented sausages produced by different approaches were on the opposite sides. Generally, all three traditionally produced samples were projected on the right side of the biplot map and can be described with more intense red colour, more pronounced spicy taste, intensive smoked odour and flavour and with higher chewiness. Among these samples, sample B possessed the most intense smoked odour and flavour, sample $D$ was the spiciest while the sample $\mathrm{C}$ was characterised with the highest hardness and chewiness. Apart from these, commercially produced sausages were characterized with more uniform cross section appearance and profound acidic taste and lactic acid odour. However, samples A and $C$ were considered similar in terms of hardness and chewiness, and both of them were characterized by the attributes that correlate in greater extent with F2 that F1. On the other hand, between traditionnally produced sausages, samples $C$ and $D$ were considered different in terms of spiciness. Namely, sample D was characterized as spicier and less hard in comparison to the sample C. Saltiness of the samples was judged less reliable, probably due to relatively small differences between samples in terms of this attribute which confused their ranking among assessors. Similar finding was observed by Bredie et al. (2018) who investigated flash profile reliability in sensory evaluation of model wine system. 

sausages, Food and Feed Research, 47 (1), 55-63, 2020

\section{CONCLUSIONS}

Flash Profile was performed on a selection of dry fermented sausages and based on their relative positioning sensory diversity of products was analysed. Traditionally produced samples of dry fermented sausages were described with more intense red colour, more pronounced spicy taste, intensive smoked odour and flavour and with higher chewiness. On the other hand, commercially produced sausages were characterized with more uniform cross section appearance and profound acidic taste and lactic acid odour. Generally, the applied Flash sensory profile technique provided a good discrimination between traditional and commercial dry fermented sausages, and proved to be a quick substitute method and also a good help as an initial comprehension of the most important attributes of a product's set. It could also be used like a preliminary phase of a conventional sensory profiling: the authors are currently conducting such a study where FP provided the attributes for the descriptive analysis.

\section{ACKNOWLEDGEMENTS}

This paper is a result of the research supported by the projects financed by the Ministry of Science and Technological Development, Republic of Serbia (Grant No: TR31029) and Provincial Ministry for High Education and Scientific Research of Republic of Serbia (Grant No: 142-4512578/2019-03).

\section{REFERENCES}

1. Aguiar, L.A.D., Melo, L., de Lacerda de Oliveira, L. (2019). Validation of rapid descripttive sensory methods against conventional descriptive analyses: A systematic review. Critical Reviews in Food Science and Nutrition, 59 (16), 2535-2552.

2. Albert, A., Varela, P., Salvador, A., Hough, G., Fiszman, S. (2011). Overcoming the issues in the sensory description of hot served food with a complex texture. Application of $Q D A ®$, flash profiling and projective mapping using panels with different degrees of training. Food Quality and Preference, 22, 463-473.

3. Blancher, G., Chollet, S., Kesteloot, R., Nguyen, D., Cuvelier, G., Sieffermann, J.-M. (2007). French and Vietnamese: how do they describe texture characteristics of the same food? A case study with jellies. Food Quality and Preference, 18, 560-575.
4. Brandt, M.A., Skinner, E.A., Coleman, J.A. (1963). Texture profile method. Journal of Food Science, 28, $404-409$.

5. Bredie, W.L., Liu, J., Dehlholm, C., Heymann, H. (2018). Flash Profile Method. In Descriptive analysis in sensory evaluation. Eds. S.E. Kemp, J. Hort, T. Hollowood, John Wiley \& Sons, pp. 513-533.

6. Cairncross, S., Sjostrom, I. (1950). Flavor profile. A new approach to flavor problems. Food Technology, 4, $308-311$.

7. Dairou, V., Sieffermann, J.-M. (2002). A comparison of 14 jams characterized by conventional profile and a quick original method, flash profile. Journal of Food Science, 67, 826834.

8. Dehlholm, C., Brockhoff, P.B., Meinert, L., Aaslyng, M.D., Bredie, W.L.P. (2012) Rapid descriptive sensory methods - comparison and validation of free multiple sorting, partial napping, napping, flash profiling and conventional profiling. Food Quality and Preference, 26, 267-277.

9. Delarue, J. (2014). Flash Profile. Novel Techniques in Sensory Characterization and Consumer Profiling, CRC Press, Taylor and Francis Group, Boca Raton, London, New York, pp.175-202.

10. Delarue, J., Loescher, E. (2004). Dynamics of food preferences: a case study with chewing gums. Food Quality and Preference, 15, 771779.

11. Delarue, J., Sieffermann, J.-M. (2004). Sensory mapping using Flash profile. Comparison with a conventional descriptive method for the evaluation of the flavour of fruit dairy products. Food Quality and Preference, 15, 383-392.

12. Jaros, D., Thamke, I., Raddatz, H., Rohm, H. (2009). Single-cultivar cloudy juice made from table apples: an attempt to identify the driving force for sensory preference. European Food Research and Technology, 229, 51-61.

13. Lassoued, N., Delarue, J., Launay, B., Michon, C. (2007). Baked product texture: correlations between instrumental and sensory characterrization using Flash Profile. Journal of Cereal Science, 48, 133-143.

14. Lawless, H.T., Heymann, H. (2010). Sensory Evaluation of Food. Principles and Practices, $2^{\text {nd }}$ ed., Springer, New York.

15. Meilgaard, M.C., Civille, G.V., Carr, B.T. (1991). Sensory Evaluation Techniques, $2^{\text {nd }}$ ed., CRC Press, Boca Raton, FL.

16. Moussaoui, K.A., Varela, P. (2010). Exploring consumer product profiling techniques and their linkage to a quantitative descriptive analysis. Food Quality and Preference, 21, 1088-1099.

17. Rason, J., Le'ger, L., Dufour, E., Lebecque, A. (2006). Relations between the know-how of small scale facilities and the sensory diversity of traditional dry sausages from the MassifCentral in France. European Food Research and Technology, 222, 580-589.

18. Stampanoni, C.R. (1993). The quantitative flavor profiling technique. Perfumer and Flavorist, 18, $19-24$. 

sausages, Food and Feed Research, 47 (1), 55-63, 2020

19. Stone, H., Sidel, J.L. (2004). Sensory Evaluation Practices, Elsevier Academic Press, London.

20. Stone, H., Sidel, J., Oliver, S., Woosley, A., Singleton, R.C. (1974). Sensory evaluation by quantitative descriptive analysis. Food Technology, 28, 24-34.

21. Tarea, S., Cuvelier, G., Sieffermann, J.-M. (2007). Sensory evaluation of the texture of 49 commercial apple and pear purees. Journal of Food Quality, 30, 1121-1131.

22. Thompson, D.M.H., MacFie, H.J.H. (1983). Is there an alternative to descriptive sensory assessment? In Sensory quality in foods and beverages: definition, measurement and control. Eds. A. A. Williams, R. K. Atkin. Chichester, UK, Horwood. pp. 96-107.
23. Valentin, D., Chollet, S., Lelièvre, M., Abdi, H. (2012). Quick and dirty but still pretty good: A review of new descriptive methods in food science. International Journal of Food Science and Technology, 47 (8), 1563-1578.

24. Varela, P., Ares, G. (2012). Sensory profiling, the blurred line between sensory and consumer science. A review of novel methods for product characterization. Food Research International, 48 (2), 893-908.

25. Veinand, B., Godefroy, C., Adam, C., Delarue, J. (2011). Highlight of important product characteristics for consumers. Comparison of three sensory descriptive methods performed by consumers. Food Quality and Preference, 22, 474485.

\section{FLASH PROFILE КАО БРЗА ДЕСКРИПТИВНА АНАЛИЗА ЗА КАРАКТЕРИЗАЦИЈУ СЕНЗОРСКОГ ПРОФИЛА ТРАДИЦИОНАЛНИХ СУВИХ ФЕРМЕНТИСАНИХ КОБАСИЦА}

Дубравка Ј. Шкробот ${ }^{1}$, Јелена М. Томић ${ }^{1}$, Тамара Р. Дапчевић Хаднађев ${ }^{1}$, Александра Р. Новаковић $^{1}$, Мирослав С. Хаднађев ${ }^{1}$, Јована Д. Делић ${ }^{1}$, Муамер Ј. Мандра ${ }^{2}$

${ }^{1}$ Универзитет у Новом Саду, Институт за прехрамбене технологије у Новом Саду, 21000 Нови Сад, Булевар цара Лазара бр. 1, Србија

2 Перутнина Птуј БХ д.о.о., 71370 Бреза, Поткрајска бб, Босна и Херцеговина

Сажетак: Технике сензорске анализе су се традиционално могле поделити на оне које се изводе са панелом обучених сензорских оцењивача (аналитички поступци) и оне које се спроводе са потрошачима (хедонски тестови). Данас, овако јасна граница између два наведена приступа све више бледи. Пратећи захтеве савременог друштва и потребе индустрије за бржим и исплативијим методама дескриптивног сензорског профилирања производа, развијено је неколико метода као алтернатива класичној дескриптивној анализи. Ове методе се могу применити код полу-обучених сензорских оцењивача, па чак и код потрошача, при чему се добијају сензорски профили врло слични оним добијеним од стране високо обучених оцењивача коришћењем класичне дескриптивне анализе. Flash profile је брза описна метода код које се профилисање производа заснива на комбинацији слободног избора атрибута која је праћена поређењем производа по свим одабраним својствима применом метода рангирања. Циљ приказаног рада је сагледавање могућности примене Flash profile методе као алата за разликовање сензорских профила сувих фрерментираних кобасица које су произведене на традиционалан начин од оних које су комерцијално доступне и производе се у индустријским условима.

Кључне речи: flash sensory profile, брза дескриптивна сензорска анализа, суве форментисане кобасище, Generalized Procrustes Analysis

Received: 25 November 2019

Received in revised form: 13 January 2020

Accepted: 29 January 2020 